\title{
Bonus Demografi Sebagai Peluang Pelayanan Misi Gereja di Kalangan Muda-Mudi
}

\author{
Rahmat Kristiono \\ Sekolah Tinggi Teologi Berita Hidup \\ rasultawangmangu@gmail.com
}

\begin{abstract}
This paper describes the correlation of bonus demographics with church mission services among young people. The demographic bonus is assumed to be an opportunity for gospel outreach or preaching which has a significant influence on the growth of the church among young people. In the context of the church's mission service, the demographic bonus has not been optimally optimized by the church, especially to place millennials on the mission objectives of the church.
\end{abstract}

Keywords: demographic bonuses, opportunities, church mission services, young people.

Abstrak: Tulisan ini mendeskripsikan korelasi bonus demografi dengan pelayanan misi gereja di kalangan muda-mudi. Bonus demografi diasumsikan sebagai peluang penjangkuan atau pemberitaan injil yang membawa pengaruh signifikan bagi pertumbuhan gereja dikalangan mudamudi. Dalam konteks pelayanan misi gereja, Bonus demografi belum dioptimalkan secara maksimal oleh gereja terutama menempatkan kaum milenial pada sasaran misi gereja.

Kata kunci: bonus demografi, peluang, pelayanan misi gereja, muda-mudi

\section{PENDAHULUAN}

Indonesia adalah sebuah negara yang sangat kaya sumber daya alam dan sumberdaya manusianya. Kekayaan indonesia dapat dilihat dari bentangan kepulauaan dari Sabang sampai Maraoke dan dari Miangas sampai Pulau Rote. Indonesia memiliki beragam suku dan bahasa serta agama yang beragam. Kekayaan Indonesia juga tercermin pada besarnya jumlah penduduk. Jumlah penduduk Indonesia berdasarkan data Badan Perencanaan Pembangunan Nasional (BAPENAS) tahun 2013, mencapai 265 juta jiwa yang terdiri dari 133,17 juta jiwa laki-laki dan 131,88 juta jiwa perempuan ${ }^{1}$

Sementara itu, hasil mutakhir sensus 2010 juga menunjukkan tren positif dengan jumlah penduduk usia produktif (15-64 tahun) tahun 2010 mencapai 66 persen dari total penduduk yang mencapai 157 juta jiwa. Adapun pekerja usia muda (15-24 tahun) mencapai 26,8 persen atau 64 juta jiwa. Angka usia produktif kerja naik dengan angka ketergantungan, 100 penduduk usia produktif menanggung 51 orang penduduk tidak produktif . Ini artinya ada bonus demografi penduduk diusia produktif yang cukup banyak yaitu $66 \%$. Jika peluang bonus demografi yang berfokus pada kaum muda-mudi

\footnotetext{
${ }^{1}$ www.databoks.katadata.co.id Akses TGl 12 Sep 2018 Jam 21.32
} 
dimanfaatkan secara maksimal oleh gereja, maka tidak menutup kemungkinan gereja akan mengalami pertumbuhan secara kuantitas maupun kualitas generasi berikutnya.

Sebagai kunci permasalahan dalam tulisan ini adalah bagaimana memanfaatkan peluang bonus demografi dengan pelayanan misi gereja dikalangan kaum muda-mudi yang berdampak pada pertumbuhan gereja baik secara kualitas maupun kuantitas. Akankah gereja melihat sebagai sebuah peluang dan meningkatkan program pelayanan misi bagi kaum muda-mudi?. Kerangka konseptual untuk permasalahan tersebut adalah sejauh mana bonus demografi dapat dimanfaatkan sebagai peluang pelayanan misi gereja dikalangan kaum muda-mudi dan pengaruhnya terhadap pertumbuhan gereja.

Pembahasan dalam tulisan ini akan dibagi dalam beberapa sub-bagian. Pertama, menjelaskan metode penelitian yang digunakan dalam penelitian ini. Kedua, menjelaskan bonus demografi di indonesia, Ketiga, menjelaskan pertumbuhan gereja dan misi, Keempat, menjelaskan transformasi bonus demografi pengaruhnya terhadap pertumbuhan gereja dikalangan muda-mudi, Kelima, simpulan atas hasil analisis dalam penelitian ini.

\section{METODE PENELITIAN}

Penelitian ini menggunakan metode analisis deskriptif kualitatif berbasis kajian kepustakaan (library research). Yang dimaksudkan sebagai analisis deskriptif kualitatif ialah analisis yang didasarkan pada pemetaan permasalahan yang terdapat dalam dua variabel kasus untuk dicari titik korelasinya. Korelasi tersebut dapat mengonfirmasi, menolak, dan seimbang berdasarkan pada pengumpulan data yang dilakukan peneliti. Studi kepustakaan merupakan instrumentasi penelitian dengan mengumpulkan berbagai macam literatur relevan, baik jurnal, buku, web internet, proceeding maupun working paper, yang memiliki tersangkut paut dengan permasalahan penelitian ini.

Berikut adalah langkah-langkah yang ditempuh untuk menganalisis data di lapangan. Pertama adalah melakukan studi pendahuluan dengan meneliti recording data laporan bilangan Research center penelitian tentang dinamika spiritualitas generasi muda kristen Indonesia. Kedua adalah mengumpulkan literatur yang sesuai dengan fokus permasalahan yang menjadi tema utama penelitian ini. Ketiga adalah menganalisis secara kritis berbagai sumber literatur tersebut untuk mendapatkan pemahaman mendasar mengenai korelasi bonus demografi dengan misi gereja dikalangan muda-mudi. Keempat adalah melakukan komparasi dengan data lain untuk menemukan lokus korelasi dan permasalahannya. Kelima adalah menulis makalah berdasarkan argumentasi analisis dari berbagai data tersebut.

\section{Bonus Demografi di Indonesia}

Demografi dari segi kata merupakan istilah yang berasal dari bahasa Yunani demos yang artinya rakyat atau penduduk dan grafien yang berarti mengambarkan atau menuliskan. Oleh karena itu, demografi dapat diartikan sebagai tulisan atau gambaran tentang penduduk. Istilah demografi pertama kali dipakai oleh Achille Guillard pada tahun 1855 dalam karyanya yang berjudul "elements de statistique humaine, ou demographie 
comparee. $^{2}$ Johan Sussmilch, berpendapat bahwa demografi adalah ilmu yg mempelajari hukum Tuhan yang berhubungan dengan perubahan-perubahan pada manusia yg terlihat dari jumlah kelahiran, kematian dan pertumbuhan. ${ }^{3}$ Sementara itu Achile Guillard, memberikan pendapat demografi adalah ilmu yg mempelajari segala sesuatu dari keadaan dan sikap manusia yang dapat diukur, yaitu meliputi perubahan secara umum, fisiknya, peradabannya, intelektualitasnya, dan kondisi moralnya. ${ }^{4}$

Dari trimonolgi kata dan pendapat para ahli prihal demografi maka dapat disimpulkan bahwa demografi adalah gambaran atau tulisan tentang keadaan penduduk yang mencatat informasi kelahiran, kematian dan pertumbuhan penduduk pada suatu daerah tertentu/negara tertentu yang dapat mempengaruhi tatanan sosial, ekonomi, budaya, moralitas dan intelektualitas serta relegius masyarakat.

Berdasarkan data sensus penduduk 2010 ada tren positif dengan jumlah penduduk usia produktif (15-64 tahun) tahun 2010 mencapai 66 persen dari total penduduk yang mencapai 157 juta jiwa. Adapun pekerja usia muda (15-24 tahun) mencapai 26,8 persen atau 64 juta jiwa. Angka usia produktif kerja naik dengan angka ketergantungan, 100 penduduk usia produktif menanggung 51 orang penduduk tidak produktif. Ini artinya ada bonus demografi penduduk diusia produktif yang cukup banyak yaitu $66 \%$.

Parameter yang digunakan dalam menilai fenomena Bonus Demografi adalah Dependency Ratio atau Rasio Ketergantungan, yaitu merupakan rasio yang menggambarkan perbandingan antara jumlah penduduk usia nonproduktif (kurang dari 15 tahun dan diatas 64 tahun) dan penduduk usia produktif (15 - 64 tahun). Angka Rasio Ketergantungan ini menunjukkan beban tanggungan penduduk usia produktif terhadap penduduk usia non produktif. Pada saat angka rasio ketergantungan rendah, kondisi ini memperlihatkan bahwa penduduk usia produktif hanya menanggung sedikit penduduk usia nonproduktif. $^{5}$

\section{Pertumbuhan Gereja dan Misi}

Gereja merupakan kata yang diambil dari bahasa indonesia dari bahasa Portugis igreja. Bahasa Portugis selanjutnya mengambil dari bahasa latin yang mengadopsi dari bahasa Yunani ekklesia dari kata ek artinya keluar dan kata kaleo artinya memanggil. Jadi ekklesia berarti kumpulan orang yang dipanggil keluar dari dunia ini. ${ }^{6}$ Sementara itu Donald Guthrie menjelaskan bahwa gereja berasal dari bahasa yunani Ekklesia terjemahan dari kata ibrani qahal yang memiliki arti perhimpunan umat Allah, maka Ekklesia dapat diartikan sebagai himpunan umat Allah yang secara khusus memiliki hubungan dengan Mesias. $^{7}$ Ichwe G Indra mendefinisikan Gereja sebagai lembaga ilahi yang didirikan oleh

\footnotetext{
${ }^{2}$ Sri Moertiningsih Adioetomo dan Omas Bulan Samosir, Dasar-Dasar Bonus Demografi Edisi 2 (Lembaga demografi: Fakultas ekonomi Universitas Indonesia, 2010), 1

${ }^{3}$ Ibid, 2

${ }^{4}$ Ibid,

${ }^{5}$ https://media.neliti.com/media/publications/73520-ID-analisis-bonus-demografi-sebagaikesempa.pdf, diunduh Tgl 25 Feb 2019 Jam 15.37 WIB

${ }^{6}$ Sentot Sadono, Doktrin Baptis: diantara pandangan teologia Kristen, (Semarang: STBI, 2011), 329

${ }^{7}$ Donald Gutrhrie, Teologia Perjanjian Baru 3 (Jakarta: BPK Gunung Mulia, 2001), 33
} 
Tuhan Yesus Kristus dan di atas dasar Yesus Kristus (Mat. 16:18; 1Kor. 3:11). ${ }^{8}$ Jadi gereja adalah kumpulan orang-orang percaya kepada Tuhan Yesus Kristus yang dipanggil keluar dari dunia yang penuh dengan dosa menuju pada Sorga yang penuh dengan kemuliaan.

Secara universal gereja terdapat dalam Matius 16:18; 1Kor 15:9; Efesus 1:22; Kolose 1:18. Gereja dalam arti sempit yaitu kesetempatan dapat diartikan sebagai persekutuan setempat yang terbentuk dari orang-orang percaya dan mengakui Yesus sebagai Tuhan dan Juruslamat, yang sudah dibaptiskan dan telah mengikat diri dalam suatu organisasirohani untuk melayani Tuhan dan sesama. ${ }^{9}$ Dalam penilitian ini yang dimaksud dengan Gereja adalah gereja setempat yaitu berbicara gereja sebagai organisasi rohani yang menentukan arah organisasi pada pertumbuhan secara kualitas dan kuantitas.

Mengacu pada Pola hidup Gereja mula-mula didalam Kisah Para Rasul 2:42-47, gereja yang bertumbuh memiliki kehidupan yang bersekutu, saling membangun, berbakti, menyembah Allah, melayani dan menginjili. Ketika pola kehidupan tersebut mengakibatkan ayat 47 berbunyi "dan tiap-tiap hari Tuhan menambahkan jumlah mereka dengan orang yang diselamatkan". Rick Warren berpendapat bahwa gereja yang bertumbuh digerakan oleh tujuan bukan oleh kekuatan lainnya. ${ }^{10}$ Salah satu kekuatan gereja mula-mula adalah pemberitaan injil. ${ }^{11}$ Dan pesan pemberitaan Injil sudah Tuhan Yesus berikan kepada gereja pada masa kini, pesan tersebut dikenal dengan Amanat Agung yang berbunyi "Karena itu pergilah, jadikanlah semua bangsa murid-Ku dan baptislah mereka dalam nama Bapa dan Anak dan Roh Kudus, dan ajarlah mereka melakukan segala sesuatu yang telah Kuperintahkan kepadamu. Dan ketahuilah, Aku menyertai kamu senantiasa sampai kepada akhir zaman." (Mat. 28:19-20). Kata Pergilah dan Jadikan Murid merupakan tujuan yang Tuhan kehendaki untuk dilakukan gereja-gereja pada masa sekarang. Jadi dapat disimpulkan bahwa Gereja yang bertumbuh adalah gereja yang digerakan oleh tujuan Allah untuk memberitakan Injil kepada semua suku bangsa.

Membicarakan pemberitaan Injil maka kita akan berjumpa dengan istilah misi. Mision merupakan istilah yang komprehensif, mencakup pelayanan gereja ke atas, ke dalam dan keluar. Gereja "diutus" seperti seseorang yang melakukan perjalanan rohani, seorang asing, seorang saksi, seorang nabi, dan seorang hamba, sebagai garam dan terang ke dalam dunia ini (Mat.5:13-16). Allah mempunyai misi (Misio Dei) untuk memahami gereja sebagai agen misi secara etimologi dari bahasa Latin "Misio" sama dengan "pengutusan"; Arie de Kuyper menulis :Bahasa Latin "Misio" = pengutusan.

\footnotetext{
${ }^{8}$ Ichwei G. Indra, Teologi Sistematik: Pengetahuan lanjutan bagi Kaum Awam dan Anggota Gereja (Bandung: Lembaga Literatur Baptis, 1999), 175.

${ }^{9}$ GGBI, Laporan kongres VII GGBI (Cisarua: GABungan Gereja Baptis Indonesia, 2000), 122.

${ }^{10}$ Rick Warren, Pertumbuhan Gereja Masa Kini (MALANG: Gandum Mas, 2000), 86

${ }^{11}$ Harls Evan R. Siahaan, "Karakteristik Pentakostalisme Menurut Kisah Para Rasul," DUNAMIS: Jurnal Teologi dan Pendidikan Kristiani 2, no. 1 (2017): 12-28, www.sttintheos.ac.id/ejournal/index.php/dunamis. band: Sonny Eli Zaluchu, "Eksegesis Kisah Para Rasul 2:42-47 Untuk Merumuskan Ciri Kehidupan Rohani Jemaat Mula-Mula Di Yerusalem," EPIGRAPHE: Jurnal Teologi dan Pelayanan Kristiani 2, no. 2 (2018): 72-82, accessed November 1, 2018, http://www.stttorsina.ac.id/jurnal/index.php/epigraphe.
} 
Inggris/Jerman/Prancis: "Mision"; Belanda"Misie" dipergunakan dalam gereja Roma Katolik, gereja Protestan pada umumnya memakai kata "Zending". Dalam bahasa Inggris dalam bentuk Tunggal "Mision" berarti karya Allah (God's Mision) atau tugas yang diberikan Tuhan kepada kita (Our Mision), sedangkan bentuk jamak menandakan kenyataan praktis atau pelaksanaan pekerjaan itu untuk Foreign Mision (Lembaga PI di luar negeri); Histori of mision (Sejarah PI). ${ }^{12}$

Maka dapatlah dimegerti bahwa pemilihan Israel, pengutusan para nabi, pengutusan Kristus ke dunia, pengutusan para rasul dan pekabaran Injil kepada bangsa-bangsa melalui gereja Tuhan dapatlah dikatakan sebagai "Misio Ecclesae" (Pengutusan gereja = pekerjaan misioner dari jemaat Kristen sepanjang sejarah dunia." ${ }^{13}$

Jadi Misi adalah keseluruhan karya Allah atas dunia dalam pengutusanNya yang diwujudkan dalam Self revelation of God yaitu penyataan diri Allah dalam melaksanakan rencana Allah yang kekal. Misi tidak terlepas dari Allah, karena berkaitan dengan Misio Dei. Allah adalah Allah yang hidup, Allah yang bertujuan dan Allah yang terlibat dalam sejarah dunia, Allah yang ada sekarang di sini, Allah adalah Allah yang sekarang sedang mengerjakan rencana-Nya dan Dia adalah Allah yang tidak berdiam diri di tempat, Ia adalah Allah Misi.

Misi adalah nafas gereja maka yang dilakukan gereja adalah menargetkan jenis-jenis orang tertentu bagi penginjilan dan prinsip tersebut alkitabiah. Yesus memberikan intruksi kepada murid-murid Nya untuk menargetkan pelayanan, seperti yang ditulis oleh Matius 10: 5-6 berbunyi: "Kedua belas murid itu diutus oleh Yesus dan Ia berpesan kepada mereka: "Janganlah kamu menyimpang ke jalan bangsa lain atau masuk ke dalam kota orang Samaria,melainkan pergilah kepada domba-domba yang hilang dari umat Israel." Paulus menargetkan pelayanannya kepada orang-orang bukan Yahudi dan Petrus menargetkan pelayanan nya kepada orang-orang Yahudi (Gal 2:7). Secara lebih jelas target pelayanan penginjilan Gereja terkandung dalam Amanat Agung, Muridkan semua bangsa istilah Yunani ta ethne (dari kata ini ditemukan kata ethnic) secara harafiah menunjuk kepada semua bangsa. ${ }^{14}$ Jadi gereja harus menetapkan target atau sasaran kelompok yang akan dijangkau. Langkah awal untuk menentukan target penginjilan adalah dengan mengumpulkan data dan informasi masyarakat disekitar gereja.

Menentukan target penginjilan atau misi gereja dapat dilakukan secara demografis. Menentukan sasaran penginjilan secara demografis akan memudahkan gereja menjangku sasaran karena gereja akan mengetahui karakter masyarakat, mengetahui informasi jumlah masyarakat. Rick warren berpendapat bahwa fakta demografis dapat menjadi sumbangsih bagi penginjilan, fakta-fakta demografis yang dapat digunakan adalah pertama, Usia (berapa banyak orang yang terdapat dalam setiap kelompok usia?), kedua, status pernikahan (berapa banyak orang dewasa yang masih bujang? Berapa banyak yang sudah

\footnotetext{
${ }^{12}$ Arie de Kuiper, Missiologia. (Jakarta: BPK Gunung Mulia, 1996), 10.

${ }^{13}$ Ibid

${ }^{14}$ Adi Putra, "Memahami Bangsa-Bangsa Lain Dalam Injil Matius," BIA: Jurnal Teologi dan Pendidikan Kristen Kontekstual 1, no. 2 (2018): 45-51, http://www.jurnalbia.com/index.php/bia.
} 
menikah?), ketiga, pendapatan (berapa gaji rata-rata yang diperoleh golongan menengah dan yang di bawah menengah?), keempat, Pendidikan (apa tingkat pendidikan dari masyarakat?), kelima, Pekerjaan (pekerjaan macam apa yang paling banyak dilakukan?). fakta tersebut akan mempengaruhi cara gereja melayani orang dan cara gereja menyemapaikan kabar baik. ${ }^{15}$ Jadi gereja yang menentukan sasaran atau target penjangkuan melalui pendekatan fakta-fakta demografis adalah gereja yang mengunakan peluang yang ada.

Berdasarkan uraian diatas maka penulis mengambil sebuah kesimpulan, gereja adalah setempat yaitu berbicara gereja sebagai organisasi rohani yang menentukan arah organisasi pada pertumbuhan secara dinamis melalui pelayanan misi pengabaran Injil kepada semua bangsa dengan memanfaatkan segala peluang yang Tuhan berikan salah satunya adalah mengunakan data demografi kependudukan untuk menentukan sasaran penginjilan.

Sasaran penginjilan yang dimaksud dalam penilitian ini adalah kelompok muda mudi di usia 15 tahun sampai dengan 25 tahun. B.S. Sidjabat mengolongkan usia 13-18 tahun sebagai usia remaja dan usia 18 - 22 tahun sebagai usia pemuda dan dewasa awal. ${ }^{16}$ Jadi dalam peneilitian ini usia yang dimaksud adalah usia Muda remaja, dimana pada usia ini adalah masa produktif dan pembentukan sepiritulitas dan intelektualitas. Usia 15-25 tahun merupakan usia masa peralihan dari usia anak-anak dan usia kematangan tahap awal atau dikenal dengan masa dewasa awal.

\section{PEMBAHASAN}

\section{Transformasi Bonus Demografi dan Pertumbuhan Gereja}

Bilangan research center memberikan laporan hasil penelitian prihal Dinamika Spiritulitas Generasi Muda Kristen Indonesia dengan mengambil populasi Generasi Muda yang berusia 15-25 tahun laki-laki maupun perempuan dari 42 kota yang meliputi koridor Sumtara, Kalimantan, Jabodetabek, Jawa, Sulawesi, Bali Nusra, Maluku dan Papua, jumlah sampel keseluruhan ada 4,095 responden yang tersebar di 42 kota. $^{17}$ Mengingat keterbatasan ruang lingkup penelitian ini, maka peneliti hanya membahas hasil data penelitian Bilangan research center pada instrumen dinamika spiritualitas dan relegiositas, menurut peneliti instrumen tersebut relevan dengan tujuan yang ingin dicapai dalam penelitian ini yaitu untuk menguji sejauh mana peranan gereja dalam memanfaatkan bonus demografi sebagai peluang misi yang membawa dampak pada pertumbuhan gereja.

Pertanyaan siapakah yang paling berjasa dalam menentukan responden untuk menerima Tuhan Yesus sebagai Juruslamat?. Bilangan research center memberikan laporan $73,1 \%$ responden mereka sudah menerima Tuhan Yesus sebagai Tuhan dan

\footnotetext{
${ }^{15}$ Rick Warren, Pertumbuhan Gereja Masa Kini (MALANG: Gandum Mas, 2000), 169

${ }^{16}$ B.S. Sidjabat, Ed.D, Mengajar secara profesional, (Bandung: Yayasan Kalam hidup, 2011), 147,150

${ }^{17}$ Bambang Budijanto, Ph.D, Dinamika Spiritulitas Generasi Muda Kristen Indonesia (Jakarta: Yayasan Bilangan Research Center, 2018), 17-18
} 
Juruslamat melalui orang tua (ayah dan ibu) dan prosentase tertinggi kedua adalah pendeta (Gembala jemaat) dengan $10,6 \%{ }^{18}$ Jika di tabelkan sebagai berikut. ${ }^{19}$

Tabel 1

\begin{tabular}{|l|l|c|}
\hline PERTANYAAN & JAWABAN & PROSENTASE \\
\hline \multirow{4}{*}{$\begin{array}{l}\text { Siapakah yang membawa } \\
\text { sudara/i untuk menjadi } \\
\text { orang Kristen yang } \\
\text { sungguh-sungguh atau lahir } \\
\text { baru }\end{array}$} & Ayah / ibu (ortu) & 73,1 \\
\cline { 2 - 3 } & Pendeta & 10,6 \\
\cline { 2 - 3 } & Diri sendiri & 2,2 \\
\cline { 2 - 3 } & Guru agama di sekolah & 1,1 \\
\cline { 2 - 3 } & Kakak & 1,7 \\
\cline { 2 - 3 } & Teman diluar sekolah & 1,5 \\
\cline { 2 - 3 } & Teman di sekolah & 1,2 \\
\cline { 2 - 3 } & missionaris & 1,1 \\
\cline { 2 - 3 } & $\begin{array}{l}\text { Salah satu guru disekolah } \\
\text { (bukan guru agama) }\end{array}$ & 0,9 \\
\cline { 2 - 3 } & Kakak rohani & \\
\hline
\end{tabular}

Pertanyaan selanjutnya adalah: Pada usia berapakah sudara/i mengambil keputusan untuk percaya pada Tuhan Yesus? Jawaban responden yang di laporkan oleh Bilangan research center dapat dilihat dalam tabel berikut ini.

Tabel. 2

\begin{tabular}{|l|c|c|}
\hline Pertanyaan & $\begin{array}{c}\text { Jawaban } \\
\text { Satuan Tahun }\end{array}$ & Prosentase \\
\hline \multirow{4}{*}{$\begin{array}{l}\text { Pada usia berapakah } \\
\text { sudara/i mengambil } \\
\text { keputusan untuk percaya } \\
\text { pada Tuhan Yesus? }\end{array}$} & $4-9$ & 9,3 \\
\cline { 2 - 3 } & $10-14$ & 4,9 \\
\cline { 2 - 3 } & $15-18$ & 13.1 \\
\cline { 2 - 3 } & $19-25$ & 28,5 \\
\cline { 2 - 3 } & $>25$ & 26,3 \\
\cline { 2 - 3 } & Tidak ingat & 4,3 \\
\hline
\end{tabular}

Pertanyaan selanjutnya adalah: Siapakah yang paling berperan dalam menolong anda mengambil keputusan mengikut Tuhan Yesus?. Bilangan research center memberikan laporan Jawaban tertinggi adalah Ayah dan Ibu (orang tua) dengan prosentase 50,5\% dan jawaban tertinggi kedua adalah Hamba Tuhan/pendeta (37,9\%) dan tertinggi ketiga adalah teman dengan prosentase $11,1 \%$.

Pertanyaan yang tidak kalah menariknya adalah: Apa alasan utama tidak lagi mengikuti ibadah di gereja secara rutin? Bilangan research center memberikan laporan yang dapat dilihat pada tebel berikut ini:

\footnotetext{
${ }^{18}$ Ibid, 27

${ }^{19}$ Ibid, 28
} 
Tabel 3

\begin{tabular}{|c|c|c|}
\hline PERTANYAAN & JAWABAN & PROSENTASE \\
\hline \multirow{10}{*}{$\begin{array}{l}\text { Apa alasan utama } \\
\text { tidak lagi mengikuti } \\
\text { ibadah di gereja } \\
\text { secara rutin? }\end{array}$} & Kesibukan sekolah & 21,4 \\
\hline & Membosankan & 13,9 \\
\hline & $\begin{array}{l}\text { Tidak punya teman di } \\
\text { gereja }\end{array}$ & 11,2 \\
\hline & Kesulitan transportasi & 9,9 \\
\hline & Malu pada teman & 4,1 \\
\hline & Dilarang orangtua & 2,7 \\
\hline & $\begin{array}{c}\text { Pindah rumah tidak ada } \\
\text { gereja disekitar rumah } \\
\text { baru }\end{array}$ & 2,7 \\
\hline & Kesiangan bangun tidur & 2,7 \\
\hline & malas & 2,4 \\
\hline & Tidak menjawab & 11,9 \\
\hline
\end{tabular}

Sementara itu laporan Bilangan research center melaporkan 8\% atau sekitar 399 responden mengatakan bahwa mereka tidak mengikuti ibadah/kebaktian kaum muda/remaja di gereja. Dan laporan yang berhubungan dengan sahabat akarab paling dominan didominasi lingkungan sekolah sebesar 67,4\% dan sementara lingkungan gereja hanya menempati $11,9 \% .^{20}$ Dari analisa data Bilangan research center melaporkan bahwa hal yang menyebabkan responden tidak menghadiri ibadah pemuda dan remaja karena program dan ibadah gereja tidak menarik, jawaban menempati prosentse sebesar $50 \%$.

Berdasarkan temuan di atas peneliti menyimpulkan bahwa, peranan orang tua untuk mengarahkan anak-anaknya untuk percaya Yesus Kristus sangat signifikan. Pembina iman yang paling dominan adalah orang tua dan Gembala Jemaat/pendeta. Usia dominan ketika menerima Tuhan Yesus Kristus adalah pada ring usia 10 tahun sampai dengan 25 tahun. Jika kita bercermin pada demografi indonesia dan fenomena demografi dimana generasi produktif di usia 15 tahun sampai dengan 65 tahun merupakan generasi yang paling dominan yaitu $70 \%$ dari keseluruhan penduduk indonesia. Fenomena ini akan mengalami puncaknya pada tahun 2020 sampai tahun 2030. Generasi ini akan dipengaruhi dengan kemajuan dan penguasaan teknologi. Merujuk pada tabel.2 usia produktif untuk menerima Tuhan Yesus Kristus berada pada ring 10-25 tahun dalam demografi kelompok ini termasuk pada kelompok usia produktif.

\section{KESIMPULAN}

Fenomena bonus demografi yang terjadi di indonesia akan mengalami puncaknya pada tahun 2020 dan berakahir ditahun 2040. Bonus demografi akan menjadi peluang besar buat gereja untuk menjangkau pada kelompok generasi muda-mudi atau dikenal dengan generasi produktif. Berdasarkan temuan dalam penelitian ini gereja belum memaksimalkan pelayanan yang berpusat pada generasi muda remaja. Gereja harus

\footnotetext{
${ }^{20}$ Ibid, 51
} 
memperhatikan fenomena bonus demografi ini sebagai suatu berkat luar biasa dari Tuhan untuk menuai jiwa-jiwa bagi kemuliaan Tuhan karena peluang ini tidak akan datang untuk kedua kalinya. Kekuatan yang bisa dan efektif untuk dilakukan gereja dalam menjangkau generasi muda-mudi adalah melalui pembinaan keluarga yang missioner dan membuat tridman program dan model ibadah pemuda yang dapat mengakomodir jiwa muda-mudi. Gereja juga harus bisa memperkuat komunitas kaum muda-mudi, keteladanan jemaat dalam gereja yang dipraktekkan dalam kehidupan keluarga harus lebih ditingkatkan, Pemberitaan Firman Tuhan yang berbobot, gereja menciptakan para mentor-mentor yang fokus pada generasi muda-mudi, Gereja tidak boleh alergi dengan fenomena perubahan zaman yang terjadi, tehnologi ceyber dan pesatnya teknologi komunikasi harus dimanfaatkan sebagai saraana dalam penjangkuaan. Pemimpin jemaat / pendeta dalam laporan riset menempati prosentase kecil dalma penjangkuaan, ini menjadi penegur bagi para gembala untuk bergairah dalam penjangkuaan dan pemuridan .

\section{REFERENSI}

Adioetomo,Prof. Sri moertiningsih dan Omas Bulan Samosir. Dasar-Dasar Bonus Demografi Edisi 2. Lembaga demografi: Fakultas ekonomi Universitas Indonesia, 2010.

B.S. Sidjabat, Ed.D, Mengajar secara profesional. Bandung: Yayasan Kalam hidup, 2011. Budijanto, Bambang, Ph.D, Dinamika Spiritulitas Generasi Muda Kristen Indonesia. Jakarta: Yayasan Bilangan Research Center, 2018.

Gutrhrie, Donald. Teologia Perjanjian Baru 3. Jakarta: BPK Gunung Mulia, 2001

Indra, Ichwei G. Teologi Sistematik: Pengetahuan lanjutan bagi Kaum Awam dan Anggota Gereja. Bandung: Lembaga Literatur Baptis, 1999.

GGBI, Laporan kongres VII GGBI, Cisarua: GABungan Gereja Baptis Indonesia, 2000.

Kuiper, Arie de. Missiologia. Jakarta: BPK Gunung Mulia, 1996.

Putra, Adi. "Memahami Bangsa-Bangsa Lain Dalam Injil Matius." BIA: Jurnal Teologi dan Pendidikan Kristen Kontekstual 1, no. 2 (2018): 45-51. http://www.jurnalbia.com/index.php/bia.

Sadono, Sentot. Doktrin Baptis: diantara pandangan teologia Kristen. Semarang: STBI, 2011.

Siahaan, Harls Evan R. "Karakteristik Pentakostalisme Menurut Kisah Para Rasul." DUNAMIS: Jurnal Teologi dan Pendidikan Kristiani 2, no. 1 (2017): 12-28. www.sttintheos.ac.id/e-journal/index.php/dunamis.

Warren, Rick. Pertumbuhan Gereja Masa Kini. MALANG: Gandum Mas, 2000

WWW.databoks.katadata.co.id Akses TGl 12 Sep 2018 Jam 21.32

https://media.neliti.com/media/publications/73520-ID-analisis-bonus-demografi-sebagaikesempa.pdf, diunduh Tgl 25 Feb 2019 Jam 15.37 WIB

Zaluchu, Sonny Eli. "Eksegesis Kisah Para Rasul 2:42-47 Untuk Merumuskan Ciri Kehidupan Rohani Jemaat Mula-Mula Di Yerusalem.” EPIGRAPHE: Jurnal Teologi dan Pelayanan Kristiani 2, no. 2 (2018): 72-82. Accessed November 1, 2018. http://www.stttorsina.ac.id/jurnal/index.php/epigraphe. 